\title{
'Greenwich near London': The Royal Observatory and its London networks in the seventeenth and eighteenth centuries
}

Rebekah Higgitt

\begin{abstract}
Built in Greenwich in 1675-6, the Royal Observatory was situated outside the capital but was deeply enmeshed within its knowledge networks and communities of practice. Scholars have tended to focus on the links cultivated by the Astronomers Royal within scholarly communities in England and Europe but the Observatory was also deeply reliant on and engaged with London's institutions and practical mathematical community. It was a royal foundation, situated within one government board, taking a leading role on another, and overseen by Visitors selected by the Royal Society of London. These links helped develop institutional continuity, while instrument makers, assistants and other collaborators, who were often active in the city as mathematical authors and teachers, formed an extended community with interest in the Observatory's continued existence. After outlining the often highly contingent institutional and personal connections that shaped and supported the Observatory, this article considers the role of two early assistants, James Hodgson and Thomas Weston. By championing John Flamsteed's legacy and sharing Observatory knowledge and practice beyond its walls, they ensured awareness of and potential users for its outputs. They and their successors helped to develop a particular, and ultimately influential, approach to astronomical and mathematical practice and teaching.
\end{abstract}

\section{Introduction}

Founded in 1675, the Royal Observatory at Greenwich is often said to have been Britain's first government-funded scientific institution. But to what extent could it, in even its first century, be considered an institution? It was, after all, little more than the Astronomer Royal, provided with a salary, a place to live and work, instruments and a servant. It was not until a series of expansions in the nineteenth century that the Observatory's funded establishment was more than two people. ${ }^{1}$ The building was designed 'for the Observator's habitation and a little for Pompe' - that is, for John 
Flamsteed's use and to flatter King Charles - and it took time for the Observatory to be understood as a lasting establishment. ${ }^{2}$ Despite this, historians have often assumed institutional continuity, while tending to treat each Astronomer Royal's tenure as distinct (in our period: Flamsteed, 1675-1719; Edmond Halley, 1720-42; James Bradley, 174262; Nathaniel Bliss, 1762-64 and Nevil Maskelyne, 1765-1811). This article therefore firstly surveys the formal ways in which the observatory obtained a lasting and established role over its first century, showing that these relied on its links to London institutions. It will then consider the more extended networks surrounding it, which generated other connections to the capital. Particularly key were the knowledge- and skill-sharing practices of instrument making and use, and mathematical training and teaching. We might helpfully consider a broader group engaged in these practices as part of an extended institutional presence and influence. While scholarly correspondence networks were enormously significant, this article will focus instead on the more practical state, maritime, commercial and mercantile contexts of London.

When the Observatory was founded, and for long after, Greenwich was not London. As suggested by the title, taken from the manner in which Flamsteed's friend and former assistant Abraham Sharp directed his letters, it was proximate but separate. The Observatory was built on the site of a fortified tower within a royal park neighbouring Greenwich Palace. The park was pictured as a pastoral retreat, and it became a fashionable neighbourhood and place to walk. The view from Greenwich Hill (later often known as Flamsteed Hill), towards the city, was frequently portrayed, the river winding picturesquely between the two (Figure 1). Before the Observatory was built, Samuel Pepys bought a painting of this view by Hendrick Danckerts, showing the partially rebuilt palace below and the fire-damaged old St Paul's in the distance. He visited the 
spot on 20 March 1669 'to see the prospect of the hill, to judge of Dancre's picture' and declared 'it is a very pretty place'. ${ }^{3}$ Pepys's diaries reveal Greenwich as a pleasurable place to visit, reached with relative ease by river from London. He might take in Woolwich and Deptford on the same day, however, and the diaries are also testament to the proximity of riverside sites of professional interest to this clerk of the acts to the Navy Board.

[Figure 1: 'A View of the Observatory' and 'A View of Greenwich, Deptford and London', from the print series British Views, published by John Bowles in London, 1723-4. Wellcome Collection V13355, CC BY.]

While Greenwich had long been a place in which shipping, down river from the Port of London, was very visible, the naval and military links of Greenwich were to develop considerably after the Observatory's foundation. In Deptford were the Royal Dockyard and also Trinity House, a maritime guild responsible for the improvement of navigation and through which boys were apprenticed to ships' masters. In Woolwich, the Royal Arsenal, a site of manufacture, experiment and training of the Ordnance's artillery and engineers (from 1741 the Royal Military Academy), was a significant neighbour. The Office of Ordnance, based upriver at the Tower, was in easy reach. From the 1690s, Greenwich Palace was transformed into the Royal Hospital for Seamen and, increasingly, the village became a location associated with retired officers and mariners and the education of future seamen. The work of the Royal Observatory was on its foundation linked to a maritime context - the improvement of astronomy for the purposes of navigation - but might have evolved differently had it not been for, on the one hand, the immediacy of maritime and naval Greenwich and, on the other, the interested London 
contexts of practical mathematics, instrument making and naval and mathematical training.

Despite the navigational task defined in the warrant ordering his salary, Flamsteed's project was no less than to reform the basis of positional astronomy, which he placed above calls to meet more practical needs. ${ }^{4}$ He would, he said, have preferred that the Observatory had been located in Chelsea because it was closer to the court. ${ }^{5}$ This raises the spectre of a counterfactual history, with Flamsteed more subject to the court's demands and whims than those of his patron (Jonas Moore, the surveyor-general of the Ordnance), Royal Society fellows, government or city interests. In this scenario it is possible that the position of Astronomer Royal might not have been continued: as an institutional base, the Board of Ordnance had more continuity than an individual monarch or dynasty. It was, ultimately, Flamsteed's assistants, pupils, successors and others with an interest in the Observatory's work that ensured it was visible and linked to the interests of various London communities.

\section{Observator's habitation to Royal Observatory: the evolution of an institution}

Unlike many of the institutions considered in this special issue, the Observatory's founding warrants made no claim to creating something that would exist in perpetuity. One, dated 22 June 1675, ordered the building of 'a small observatory ... with lodging rooms'. The other, from 4 March 1674/5, noted the appointment of Flamsteed as 'our astronomical observator' and ordered the Board of Ordnance to pay him $£ 100$ per annum. ${ }^{6}$ The supply and payment of assistants, and provision and maintenance of instruments and any additional buildings, were only addressed subsequently and, in some cases, not for many years. New warrants were required for succeeding Astronomers 
Royal and even, potentially, to reconfirm an appointment when the monarch changed. ${ }^{7}$ Succession was by no means guaranteed. ${ }^{8}$ The post and the Observatory gained longevity by their connection and significance to a range of institutions and groups. The most central were a very metropolitan grouping consisting of a government department (the Board of Ordnance based at the Tower of London), the Royal Society of London and a parliamentary commission, later known as the Board of Longitude, institutionalised within the Board of Admiralty.

Over its first 100 years, the Observatory developed from being a building provided for an individual's use into an institution that could last over three centuries. Plans for its location and design were made by the King's surveyor general, Christopher Wren, and delegated to his assistant, Robert Hooke. Money and materials were to be supplied by the Ordnance, an arrangement due to the fact that the Observatory had been lobbied for by Jonas Moore. It was thus linked to a department that was at this period a centre of practical mathematics, where 'officers had the opportunity to occupy an important, perhaps uniquely influential' role in its patronage. ${ }^{9}$ While several fellows of the Royal Society had hoped to establish an observatory, and advised the king about its potential role in providing a means of finding longitude at sea, it was Moore who made the essential connections, found support at the Ordnance, and was credited as the observatory's founder. ${ }^{10}$ As Hooke noted, Moore had 'procured a patent for Flamsteed of $£ 100$ per annum and an observatory in Greenwich Park' ${ }^{11}$ He had made opportunities for many practical mathematicians within London and Flamsteed was one more example. ${ }^{12}$

This combination of royal foundation, state funding and private patronage led, as is well known, to conflicting views regarding the status of the Observatory and what might be 
expected from its observer. ${ }^{13}$ In particular, Moore had personally supplied the observatory's equipment, with subsequent additions paid for by Flamsteed, for whom private teaching, a church living and an inheritance were together more a significant source of income and capital than his salary. ${ }^{14}$ Thus Flamsteed felt as much indebted to his patron and his own resources as he did to the monarch or state, which influenced his choices about the work he undertook and how or whether he shared the results. This led to the famous clashes over calls for his observations to be published, for the use of astronomers and the public good, and to his widow, Margaret, treating the instruments as her inheritance, removing them from the Observatory and disposing of them as she wished.

Such crises were to prompt actions that helped develop the institutional nature of the Observatory and formalised previously informal practices. The first and most dramatic shift resulted from the dispute between Flamsteed and the Royal Society group which, having obtained support in 1704 from Prince George of Denmark (Queen Anne's consort and First Lord of the Admiralty), was to oversee the publication of his catalogue of stars. ${ }^{15}$ After George's death in 1708, Flamsteed stopped co-operating but found his freedom limited by the Queen's appointment, on 12 December 1710, of the President and Council members of the Royal Society as 'constant Visitors of our Royal Observatory at Greenwich'. ${ }^{16}$ They were given the right to demand that the astronomer hand over his observations every six months and to direct his observing programme. They also had the responsibility of inspecting the instruments and directing the Officers of the Ordnance to exchange or repair any that were found faulty. In fact, once Halley had published his version of the catalogue in 1712, there were few demands of Flamsteed, who ultimately 
had more friends than enemies among the Visitors. Equally, the Board of Ordnance largely ignored requests for repairs to the instruments. ${ }^{17}$

The Visitors do not appear to have played a significant role in the transition from Flamsteed to Halley as Astronomer Royal, although they supported future requests to government for the funding of instruments and extensions to the buildings, and occasionally reminded the astronomer that they had the power to demand his observations. The new warrant required for Halley's appointment was, however, an opportunity to confirm the early verbal command to the Ordnance that they supply a labourer to assist the Astronomer Royal. ${ }^{18}$ This individual had initially been placed on secondment from the Ordnance but from 1694 Flamsteed was allowed to name the individual and received an additional sum to cover pay, from which time he had his own, often indentured, servant supported by the state. ${ }^{19}$ The appointments of subsequent Astronomers Royal throughout the eighteenth century set this on proper footing: the Ordnance was told that the appointees were 'allowed and paid, in the same manner, the yearly salary of twenty six pounds for such Servant of Labourer, whom you shall make use of for that Purpose, in like manner as was allowed \& paid to, or for, the Servant of the said John Flamsteed'. ${ }^{20}$

Astronomers Royal were, by virtue of personal expertise and their official positions (each also held other appointments, whether in church, university or both), advisors to a number of bodies. These included local charities and London institutions, including the Royal Mathematical School (RMS) at Christ's Hospital and Trinity House. They were, typically, on the Council of the Royal Society, although fallings out with presidents (as happened both to Flamsteed and, at the other end of the eighteenth century, Maskelyne) 
could see them excluded. One such role was, however, made ex officio, signalling an expectation that the position of Astronomer Royal would exist as long as required. This was in the Longitude Act of 1714, which appointed a number of Commissioners to adjudicate potential methods of finding longitude at sea. The 'Royal Astronomer of Greenwich', like the president of the Royal Society, the university professors of mathematics and of astronomy and a number of political and maritime offices, was alluded to by position rather than by name. It was to be the successive holders of these positions that were to be the most active Commissioners of Longitude, particularly Bradley and Maskelyne. ${ }^{21}$

Under Halley, Bradley and Bliss, little changed in terms of the official presence of the Observatory, although they did succeed in augmenting their salaries. Queen Caroline awarded Halley a captain's half-pay for his former service as captain of the Paramour, a cost placed on the Naval Estimates. Both Halley and Bradley retained their Oxford Savilian professorships, though the latter gave up his church living. In recompense he received a pension of $£ 250$ on the Civil List, which was also paid to Bliss and Maskelyne. ${ }^{22}$ Despite the financial continuity, it was only on Maskelyne's appointment that the role of Astronomer Royal became more formalised: shortly after he was installed at the Observatory, the 'Regulations for the Astronomical Observator at Greenwich' were signed by George III. These were based Maskelyne's own earlier suggestions to the Royal Society, after he had failed to gain access to Bradley's observations. They emphasised constant superintendence of the observatory and instruments, good bookkeeping and submitting fair copies of observations to the Royal Society annually. ${ }^{23}$ It re-emphasised the authority of the Visitors over the astronomer but also ensured an 
institutional legacy and output, now increasingly required by Royal Society- and statefunded endeavours and expeditions.

For the first time, under Maskelyne, the Astronomer Royal's main series of observations was published while he was still in office. The first volume of Greenwich Observations appeared in 1774, almost exactly 100 years after Flamsteed's appointment. From 1769 Maskelyne also fulfilled the original aim of the observator's appointment by making available the means of finding longitude by astronomical observation, via the Nautical Almanac. Previously, observations had been treated as personal property. Maskelyne ensured public ownership of his own work and chased up that of his predecessors: he secured Flamsteed's and Halley's papers, purchased by the Board of Longitude in 1771 and 1765 respectively, and spent many years trying to expedite the printing of Bradley's observations. ${ }^{24}$ Under Maskelyne, in a period of greater governmental bureaucracy, both the Royal Observatory and Board of Longitude had their business regularised. ${ }^{25}$ This was underscored by a knowledge of their institutional history, which Maskelyne invested in by drawing together, as far as possible, a complete series of observations, and by collecting memorials, instructions, warrants and information on previous funding and management. ${ }^{26}$

Thus, although prints and periodicals long continued to refer to the Observatory as Flamsteed's, it slowly gained an institutional and enduring existence. This relied on its embedding within two government departments, the Board of Ordnance and, via the Board of Longitude, the Admiralty. In 1818 it was transferred to the latter as its role in supporting navigation, via the production of the Nautical Almanac, the rating of chronometers and links to naval exploration and surveying, clearly supplanted the long- 
gone personal link to the Ordnance. Over the previous century, problems had led to the clarification of roles and responsibilities, including the Royal Society's more or less formal oversight of the Astronomer Royal's work and equipment. As the Society later became more involved in advising government, the Astronomer Royal might also play an important role in ensuring they could offer crucial expertise. ${ }^{27} \mathrm{He}$ and his establishment had become an almost indispensable resource for city and nation.

\section{The extended institution: instrument makers, assistants and pupils}

Focusing on this officially documented story shows the embedding of the Observatory within the Ordnance, Royal Society and Board of Longitude, but tells us only part of the story. The Observatory also fed into these and other communities in more informal ways that underscored its role as a metropolitan institution and show the links between city and environs. These helped to create and serve a need for knowledge sharing and teaching in which the Observatory's approach to practical astronomy and mathematics played a crucial role. In addition, when we consider the broader range of people involved in these contexts, the disjuncture between each Astronomer Royal's tenure is lessened. The Observatory's establishment, while small, was always more than one person. There were assistants, computers, family members, pupils, instrument makers and other visitors. Each of these were involved in the Observatory's astronomical business, some only briefly others for most of a lifetime. Several also played a role in championing the Observatory after leaving Greenwich or, at least, took the practices, experience and knowledge gained there with them.

Because of the dispute and bad feeling between Flamsteed and Halley, and because of their differing programmes at Greenwich (focused on a star catalogue and a complete 
lunar cycle respectively), the sense of hiatus between tenures has seemed particularly clear. In addition, Halley, uniquely, appears to have had no assistants. While his warrant of appointment confirmed payment of one, there are no recorded assistants and Joseph Crosthwait, who had worked for Flamsteed and seems to have kept a close if unfriendly eye on Halley, reported in 1721 and 1728 that he had no assistant. On the first of these occasions he noted that Halley had 'lately made me an offer', which he rejected, though whether this was for him to stay on as assistant or to provide information is not clearCrosthwait feared that whatever it was might be 'prejudicial' to Flamsteed's legacy. ${ }^{28}$ Lacking an Ordnance-paid assistant, it seems likely that Halley was helped by family members. However, despite the suspicion toward Halley from Flamsteed's former assistants, we can also find evidence of continuity, not least because Flamsteed and Halley had been close before their falling out. Indeed, 'Halley was involved with the Observatory from its beginning' and, as master and protégé, the two collaborated and observed together. ${ }^{29}$ The more extended Observatory network could also bridge changes of regime. Informal institutional links, such as to the RMS and Trinity House, were retained and, as we shall see in the following sections, Flamsteed's former assistants James Hodgson and Thomas Weston remained interested in Observatory matters.

Halley had occasional assistants for particular tasks that reveal connections to his successors. George Graham, who made the new Observatory instruments, and in 1726 became a Visitor, went to Greenwich to help adjust the transit instrument on at least two and probably other occasions. The astronomer John Bevis, who later worked with Bradley and Maskelyne on matters such as the transits of Venus, was recorded as having made an observation with Halley in $1737 .{ }^{30}$ James Pound formed an important link between Flamsteed, Halley and Bradley. He observed and collaborated with Flamsteed, 
became a Visitor in 1714 , and assisted with the publication of his catalogue of stars. He succeeded to Flamsteed's living at Burstow, observed a comet with Halley in 1723/4 and perhaps at other times, while Bradley was his nephew, pupil and collaborator. ${ }^{31}$ Just as Halley had often visited the Observatory as a young man, Bradley was present on a number of occasions under Halley. For example, he joined Graham on the visits noted above and recorded that he had adjusted the transit telescope, tried its accuracy and 'likewise set the mural instrument' ${ }^{32}$ These were the instruments that Bradley was to inherit in 1742, and Graham remained an important source of knowledge and expertise. On his appointment as Astronomer Royal, Bradley had to establish the quadrant's errors and Graham took its telescope to London to adjust and add wires, a reminder of the fact that Greenwich was well placed via river for access to and by London's elite instrument makers. Based on Fleet Street, at the top of Water Lane, Graham had been apprenticed to, worked with and taken over the business of his wife's uncle Thomas Tompion, also closely associated with the Observatory's instrumentation.

Bliss and Maskelyne inherited the Graham quadrant and clocks, as well as new instruments made for Bradley by John Bird, a former assistant to Graham based in York Buildings on the Strand. As before, there was frequent crossover of Greenwich-based experience. Bliss had assisted and stood in for Bradley as he aged, while Maskelyne had collaborated closely with him at the Royal Society and in relation to the testing of Tobias Mayer's lunar tables for the Board of Longitude. Bradley effectively delegated to Maskelyne the planning of the Society's 1761 expeditions to observe the transit of Venus and the Board's trials of Mayer's tables and John Harrison's sea watch. ${ }^{33}$ These expeditions and the voyages of exploration under James Cook and others developed the relationship between the Observatory and instrument makers, as Bradley and, especially, 
Maskelyne advised on the suite of instruments to be taken to carry out observations at sea and to establish portable observatories on land. ${ }^{34}$ Through such work they acted as significant patrons.

Much more might be said about the instruments and their makers than there is space to include here. This London-based trade was essential for the Observatory to function, although arrangements were initially ad hoc. For the first equatorial sector, designed by Flamsteed with an index by Tompion, the workshops of the Tower of London were put to use in making the frame and metalwork. Isaac Thomson made up Robert Hooke's design for the 10-foot quadrant in London, while the 60-foot telescope used an object glass from Paris, acquired by Moore via the Royal Society, and was supported by an 80 -foot mast supplied by the Navy Board, via Pepys. Flamsteed's 1689 mural arc was made by his assistant Sharp. ${ }^{35}$ In the following century the established trade, with expert craftsmen and larger workshops, made London the place to go for optical and mathematical instruments. The skill of these individuals developed alongside that of the astronomers and their assistants, whose constant practice with these instruments and connections with their makers was essential to the development of the Observatory. At the same time, the growing reputation of the Observatory paid a compliment to the excellence of the instruments and the dexterity of their makers. ${ }^{36}$ By the end of the century it had become advantageous for instrument makers to advertise the connection. ${ }^{37}$

The Observatory's assistants provide direct examples of overlap and continuity but were just as significant for their role in extending relevant skills and knowledge beyond Greenwich. The list of Flamsteed's labourers, servants, apprentices, amanuenses and calculators displays the networks and geographies of London and English mathematical 
practice. ${ }^{38}$ His first labourer, Cuthbert Denton (ROG 1676-c.1680), was on secondment from the Ordnance and officially under the direction of Moore. While Denton was, Flamsteed said, 'onely fit for hard labour', the Ordnance's interest in numerate, literate and skilled individuals is underlined by the fact that Flamsteed's first personal servant, Thomas Smith (ROG 1676-84), left Greenwich for better paid roles within the Ordnance, where he assisted the clerk of deliveries and was later store keeper at Chatham Dockyard. The assistants were evidently able to make contacts and hear of opportunities at the Tower. Isaac Woolferman (ROG 1706-09) also found well-paid work within the Ordnance, which sent him out as 'conductor of the train of artillery, to Port Mahon', after the 1708 capture of Minorca. ${ }^{39}$ Samuel Clowes (ROG 1691-95), on the other hand, left without permission, 'in hopes', Flamsteed supposed, of 'preferment at sea for his skill', but was later employed as surveyor to New York.

Personal connections were, of course, important: Hodgson (ROG 1695-1702) was Wren's nephew, while Flamsteed secured several calculators in his native Derbyshire, including a relation of Halley's, Luke Leigh (calculated 1695-1705?). However, Flamsteed's most significant assistants, Sharp (ROG 1684-5 and 1688-90), Hodgson and Weston (ROG 1699-1706), show that Observatory assistant was one option among several making up mathematicians' mixed careers. Sharp may have taught writing and arithmetic in Liverpool before being employed at Greenwich and, after, probably taught mathematics to mariners when lodging at the Mariner and Anchor on Little Tower Hill. He was subsequently a clerk in the dockyard in Portsmouth before, on the death of his brother, returning to his family home in Yorkshire. He maintained his correspondence with London mathematicians and instrument makers, continued to publish and helped Crosthwait (ROG 1708-19), bring Flamsteed's Historia coelestis and Atlas coelestis to 
posthumous publication in 1725 and $1729 .{ }^{40}$ Hodgson also operated for a period within the London market, teaching mathematics in Westminster and London, around the Tower and the Royal Exchange, lecturing on natural philosophy in taverns and coffee houses, and publishing mathematical texts. He was appointed mathematical master at the RHS in 1709. ${ }^{41}$ Weston, too, became known as an author and teacher of mathematics, opening an Academy in Greenwich that became famous for producing naval officers.

Such patterns continued for Greenwich assistants throughout the eighteenth century. Increasingly, the openings came via the Admiralty rather than the Ordnance. This reflects the Astronomer Royal's opportunities for patronage via the Board of Longitude (including computing for publications, trialling longitude schemes and expeditions) and the links between Board, Observatory, Navy, crown and Royal Society that underpinned voyages of exploration from the 1760s. Each of the assistants under Bradley and Bliss John Bradley, Charles Mason and Charles Green - were also expeditionary observers appointed by the Board or Royal Society. Maskelyne had a large number of assistants and seems to have seen the low-paid role as a training opportunity from which subsequent employment could be secured, much of which he was able to provide. ${ }^{42}$

In Flamsteed's time, teaching was almost as significant a part of the Observatory's business as observation. Thanks to his assistants and relations this legacy was to continue long after his death. Once again this underlines the close similarity between careers at the Observatory and London's practical mathematicians, for whom teaching and publication were core and complementary activities, whether aimed at gentlemen, clerks, mariners or tradesmen. While Jonas Moore was alive, Flamsteed's role within this milieu was clear, for he was required to take in pupils linked to his patron's institutional bases, the 
Ordnance and the RMS. He often chafed at such obligations but also cherished the role of teacher where it suited him, including when he stood in as lecturer in astronomy at Gresham College, for which the scholars at the RMS were a principal audience. ${ }^{43} \mathrm{He}$ continued to take on pupils long after Moore's death in 1679 and even when he had less financial need after receiving a legacy in 1688 .

Flamsteed's list of more than 140 pupils ranges from RMS boys sent for short periods to seven-year indentured assistants. Although this list was only accurate 'as far as my memory will shew me', it records a variety of employments for which mathematical knowledge was required or useful. ${ }^{44}$ Flamsteed's pupils included Richard Stevenson, who was, or went on to become, a clerk at the Ordnance Office; John Wootton, collector of customs; Thomas Hannsay, clerk in the Navy Office; Thomas Gardiner, storekeeper of the Ordnance Office; John Clarke, also in the Ordnance Office; Thomas Bell, clerk in the Tower and later 'assistant Engineer at New foundland'; Samuel Heynes, clerk in the Navy Office and mathematical teacher; Joynes[?] Knightley, at the Custom House; John Baxter a Bombardier (an artillery officer within the Ordnance); and Brooke Bridges, son of the Brigadier-General Sir Matthew Bridges, who became 'one of the deputed Searchers of his Majesty's Customs'. There were a number of Captains and others who were recorded as being, or having died, overseas or at sea on ' $y$ eing's service' or ' $y$ ' [East India] Companys service' ${ }^{45}$

In 1699 Flamsteed recorded that his pupils were 'the sons of the Nobility and Gentry, designed for the Sea or Army'. He also noted that he had 'made Use of [them] to Assist me ... or my servant'. This was to underline his lack of publicly supplied resources, the onerous requirements of his post and the importance of even his private work to the 
public interest. A later draft petition made similar points, including that he had 'educated more than 100 brave Youth that have passed into the Publick service'. ${ }^{46}$ Thus, while Flamsteed did not produce texts or tables for navigators, his teaching, as well as advice on curricula, examinations and appointments at the RMS, meant that the early Observatory had some influence on practice at sea. ${ }^{47}$ The later careers of Hodgson and Weston extended this influence further. It is apt that the most-viewed contemporary representation of Flamsteed, in the Painted Hall at the Greenwich Hospital, shows him as mentor to Weston (Figure 2). In James Thornhill's 'explanation' of his painted scheme, Weston is described as Flamsteed's 'ingenious Disciple..., who is now Master of the Academy in Greenwich ${ }^{48}$ There, alongside private pupils, he taught sons of Hospital pensioners, whose education was partly funded by visitors to the Hall and purchasers of Thornhill's pamphlet. Weston's school became known for mathematical and maritime education and he followed in Flamsteed's footsteps by serving as a mathematical examiner for Trinity House, carrying out examinations of RMS pupils from 1719 until his death in $1728 .^{49}$ Weston, and probably Hodgson, had gained teaching experience at the Observatory. In February 1702/3 he was working on lunar tables and 'in the Care of a Couple of young Gentlemen Noble mens sons that are now goeing to The Indies' ${ }^{50}$

[Figure 2: John Flamsteed and Thomas Weston, with the mural arc, on the ceiling of James Thornhill's Painted Hall of the Royal Hospital at Greenwich, c. 1712. (C) Old Royal Naval College, 2019.]

Teaching in domestic spaces was, inevitably, a family matter. Margaret Flamsteed, on her marriage in 1692, appears to have been a diligent pupil and was later called 'a well wisher to the Mathematicks'. ${ }^{51}$ She would have helped attend to Flamsteed's pupils as 
lodgers, as well as receiving guests, and may have assisted with teaching. Flamsteed's niece, Ann Heming, who lived at the Observatory from 1694 to 1706, despite having married Hodgson in 1702, was amply equipped to be a mathematical master's wife when she joined him in London. ${ }^{52}$ Captain Henry Stanyan, a one-time pupil, surely acknowledged Ann's familiarity with Observatory matters, as well as impending motherhood, when he sent his 'hearty service to Mr Hodgson and his Fair spouse' on their marriage and wondered 'if they begin to propagate Astronomy'. ${ }^{53}$ Even after she moved to the city, Ann was left to oversee Flamsteed's household when he was away. ${ }^{54}$ Margaret Flamsteed's links to education also extended beyond the Observatory: in 1700, she was one of the founders of the Greenwich Girls' Charity School. This did not involve scientific or mathematical teaching, being focused on preparing girls to become servants, but allowed Margaret to exercise her mathematical talents as treasurer and auditor. ${ }^{55}$ Flamsteed appointed these two women his executors and Margaret, together with James and John Hodgson, their heirs, undertook the task of completing her husband's work.

\section{Extending and continuing Flamsteed's legacy}

The best-known aspect of the perpetuation of Flamsteed's legacy is the effort - involving Margaret Flamsteed, Hodgson, Crosthwaite, Sharp and others - to publish his posthumous works. ${ }^{56}$ Halley's 'pirated' 1712 edition of the Historia coelestis was a star catalogue with a brief preface, taking a swipe at Flamsteed, and including a frontispiece showing Prince George surrounded by maritime, riverine and astronomical iconography. ${ }^{57}$ The 1725 edition was, instead, adorned with a portrait of Flamsteed, as Regius Professor of Astronomy, collated other catalogues, to which his was a culmination, and included a lengthy historical and justificatory preface. ${ }^{58}$ Margaret Flamsteed played the major role in organising and advocating and paying for the 
publications, with Hodgson's assistance, while Crosthwaite took on the bulk of the work. ${ }^{59}$ Crosthwaite complained of not receiving a legacy from Margaret in recompense, although in 1724 she signed over six months' dividends from her South Sea Company stock to him, worth $£ 708.6 .8 .{ }^{60}$ Possibly her death in 1730 prevented her doing the same around the time of the publication of the Atlas.

Margaret Flamsteed took possession of her husband's papers as well as the Observatory's instruments. The latter were claimed as personal property and she successfully challenged the Ordnance for ownership. The fate of much of this property is unknown but the disposal of some of it is revealing. In her will, Margaret made careful choices with regard to four portraits, two each of Flamsteed and of his hero, the Danish astronomer Tycho Brahe. One pair were to be sent to the Bodleian Library 'to be hung in the Gallery where the Pictures of the Founders of Colleges and other eminent Persons hang'. This was a public space in which to make a public declaration about Flamsteed's significance and inheritance of Tycho's status. The other pair of portraits was to go to the Royal Society, and Margaret again directed their arrangement: 'to be placed where the Pictures of Mr Boyle and other persons of the learned Society are fixed' ${ }^{61}$

Margaret left 'all the right and title I have in Instruments Glasses, Copper plates, Manuscripts printed Coppys of the Historia Coelestis' not to James or Ann Hodgson but their eldest son, John (1708-1751). He also got rights to 'my Chambers in Grays Inn and a tenement in St Paul's Church yard', was the major beneficiary and sole executor. John, who was like a grandson to the Flamsteeds, was probably schooled at Christ's Hospital and became, at least by 1737 , a supercargo for the East India Company. ${ }^{62}$ He was evidently expected to inherit his father's mathematical ability; aged 11 he was acting as 
Flamsteed's amanuensis and, much later, father and son appear as subscribers to William Gardiner's 1742 Tables of Logarithms. ${ }^{63}$ However, it was the father who presented several of the inherited objects to the Royal Society and Oxford. The former received one of the Observatory's Tompion clocks and a Venetian object glass, in 1736 and 1737 respectively, as well as the portraits in 1732. This has led to speculation that Hodgson took all the instruments and perhaps used them at the RMS, but it may simply be that he took care of these gifts because he was a fellow of the Society and because his son was overseas. ${ }^{64}$ The Oxford portraits did not reach the Bodleian until 1752, after John's death. $^{65}$

Thus, while Hodgson played a relatively minor role in perpetuating Flamsteed's memory via the publication of the Historia and Atlas, he did ensure the placement of portraits and relics in the Bodleian and Royal Society. Even during Flamsteed's life, Hodgson had been a useful link at the Society. He had been elected on the same day that Newton was chosen president and Flamsteed told Sharp anxiously, 'they have a limbe of me', but reassured himself that Hodgson was 'honest and discreet and I believe and hope will not serve some mens small designs as they expect he should'. ${ }^{66}$ He was later suspected by Halley of spying on the printing of the catalogue, since he was 'living within a stones cast of the printers', and was one of the Society's Visitors to the Observatory, soothing this very difficult relationship. ${ }^{67}$ On the occasion of the first visitation, Flamsteed wrote that Hodgson had 'given me an intimation of [it] the night befor', allowing him to assemble witnesses. ${ }^{68}$ Hodgson also sought to spread Flamsteed's name and reputation and the significance of the work undertaken at the Observatory - within the London practical mathematical community. Flamsteed's catalogue and atlas were expensive 
works, published in Latin. Hodgson, however, put useful and practical elements of this work into English and a usable format.

As Flamsteed wrote of Hodgson, he was 'a very good geometrician and algebraist' and, perhaps more importantly, 'he knows my method, and is acquainted with all my labors, and will easily finish and print them'. ${ }^{69}$ As Rob Iliffe has suggested, it was surely 'no small triumph' for Flamsteed that his former assistant and nephew-in-law should have filled the problematic and contested role at the RMS in $1709 .^{70}$ In 1704 Flamsteed had called Hodgson 'the onlely skillfull teacher now in town', while recent consideration of teaching at the RMS has emphasised the latter's significance and success. ${ }^{71}$ His book The Theory of Navigation Demonstrated (1706) - a publication that advertised his suitability for such a position - followed his master in condemning teaching 'by Rules only' and encouraged the understanding of 'the Reasons, instead of their Rules and Canons' to aid retention of learning in geography, navigation and astronomy. This meant beginning with Euclid 'after the method I learn'd at Her Majesties Observatory'. ${ }^{72}$ Hodgson several times found reason to mention the Observatory. On the title page he noted the inclusion of a list of positions of several ports and cities, 'with their Longitudes from her Majesty's Observatory, deduced from Celestial Observations'. The Nautical Almanac was, of course, later to provide Greenwich as the prime meridian for surveyors' and navigators' calculations but this was an early use in such a context. Moore's A New Systeme of the Mathematics, published in 1681 for RMS pupils, provided its longitudes by 'the Geographers Meridian', the Azores. ${ }^{73}$ Hodgson also included 'a small Catalogue of the 30 Eminent Fixed Stars, all deduced from Observations made at Her Majesty's Observatory at Greenwich, where I had the happiness to have my Education' and solar 
tables for 'the Meridian of Her Majesty's Observatory', together with a table of stars' right ascensions and polar distances 'Deduced from the Greenwich OBSERVATIONS'. 74

Once in position as master, and after Flamsteed's death, Hodgson published A System of the Mathematics (1723), a replacement to Moore's text that was, likewise, 'Designed for the Use of the Royal Mathematical School' ${ }^{75} \mathrm{He}$ did much in this work to advocate for Flamsteed, the Observatory and the forthcoming Historia coelestis. He wrote of 'the Flamsteedian Observations made at Greenwich', and experiments on sound signals undertaken by 'the Reverend and Learned Mr. Flamsteed, His Majesty's Astronomer at Greenwich' ${ }^{76}$ In his section on finding longitude, the examples given by Hodgson included specific observations by Flamsteed (e.g. of eclipses of the Moon or Jupiter's satellites to establish differences in longitude across Europe) ${ }^{77}$ He echoed Flamsteed's comments on mariners' lack of mathematical skill and the usefulness of the Jupiter's satellites method of finding longitude: it 'requiring only a Telescope of eight or ten Foot in Length, which may be almost managed with the Hand'. 'It is', he wrote, 'much to be wondered at, that the more skilful Part of our Seamen have so long neglected [such observations] ${ }^{78} \mathrm{He}$ also described the lunar-distance method, which would be serviceable 'when a good Theory of the Moon shall be obtained'. ${ }^{79}$ This was, he asserted, 'already brought to very great Perfection, compared with what it was a few Years ago' and would soon be sufficiently improved by 'the great Stock of good Observations that Mr. Flamsteed has left behind', ${ }^{80}$

He urged that 'if Men would set about it in good Earnest, they would not fail to meet with Success at Sea' and recounted the experience of 'a skilful Commander', who took an 18-inch quadrant with sights and a pedestal on an East India Company voyage and 
managed to make some good observations. Such men, he suggested by way of encouragement, 'may fairly be intituled to a Share of the discovery of the Longitude, and ought to have a proportional Reward' ${ }^{81}$ He went on, 'Let us not call out for a Discovery of the Longitude as if there were no such thing in being, but let us set our selves in earnest to put the Methods hitherto known in practice, in their utmost extent, and no doubt but other and more effectual Means will be found out'. They need not wait for government to send out dedicated voyages, he said, despite others blaming their lack of action, instead,

let every one of His Majesty's Ships of War be provided with a good Telescope, a small Quadrant, and a good Time-keeper, and let the Teacher of Mathematicks appointed for that Ship, be obliged in every Port he comes into, to make all the Observations that happen during the time of his stay there; and let him be obliged at his return home, to bring them to the Royal Society, or to any Person or Set of men whom the Government shall think fit to appoint for this Purpose.... ${ }^{82}$

A version of this section had appeared within Hodgson's substantial completion of John Witty's posthumous A Treatise of the Sphere. This was published in 1714, the year of the Longitude Act, which explains the emphasis on existing solutions and immediate actions, although by 1723 the admonitions were directed at his RMS pupils. ${ }^{83}$ Witty was part of the extended Observatory circle, having been a calculator for Flamsteed's catalogue, living with the family in 1705-06. ${ }^{84}$ Hodgson's text also showed his support for another member of the Observatory network, 'the indefatigable Mr. Abraham Sharp'. This related to Sharp's method for the quadrature of the circle, which Halley had published in 1706 without acknowledgement. Hodgson, in response to Sharp's complaints and 
Flamsteed's encouragement, clarified authorship 'as a piece of Justice due from my self, to that incomparable Master of Numbers'. ${ }^{85}$

These obligations to Witty and Sharp were undertaken when Flamsteed was still alive. Although Hodgson had a permanent position he necessarily treated Flamsteed with deference as patron and senior relative. However, the second volume of his System was written after Flamsteed's death and it contains his eulogy in an extended 'Account of the Astronomical Work of the late Reverend Mr. FLAMSTEED the King's Astronomer', including a description of the content of the forthcoming Historia and brief account of the foundation of the Observatory and Flamsteed's 'indefatigable Pains and constant Application to the Heavens'. He emphasised that, 'since no advantage can arise from praising or flattering the Dead', the praise rose only 'from a great Esteem, grounded upon a just Knowledge of the Merits of so great a Man' ${ }^{86}$ This volume, too, asserted Hodgson's expectations of 'the careful and diligent Mariner' to improve knowledge of geography and navigation, made repeated mention of Flamsteed and his endeavours and claimed that his 'utmost View' had been 'to render every thing that he undertook as easy and ready for Use as might be'. ${ }^{87}$

\section{Balancing theory and practice: an Observatory style?}

Although Pepys, Newton and Flamsteed found it difficult to appoint an RMS master who could achieve the right balance between theoretical and practical knowledge, Margaret Schotte has pointed out the School's tradition of 'experiential' learning with instruments

and models, and a focus on skills such as drawing. ${ }^{88}$ In the 1680 s, under Edward Paget, a new building for the School included a rooftop observatory with an astrolabe, azimuth compass and quadrant with telescopic sights. Maps were on display and the school 
owned three pairs of celestial and terrestrial globes. ${ }^{89}$ There were, however, repeated examination failures. Hodgson set this right and was able to satisfy Trinity House, which passed and apprenticed the boys. He, apparently, 'had a reputation for involving students actively in the learning process through the use of modern mathematical and navigational instruments', although his textbook and the curriculum have been characterised as difficult and abstract. ${ }^{90}$ From 1719-28 the examiner they had usually to please was, of course, Thomas Weston, so perhaps it is unsurprising that there was agreement between these two products of the Observatory's system. They had been indentured for seven overlapping years and knew each other well.

Weston, although appreciated by Flamsteed as a draftsman, was 'an ingenious but sickly youth', received a full mathematical education and became 'expert in observing'. ${ }^{91}$ Theory and practice inevitably went hand-in-hand when training at the Observatory and Weston was understandably considered 'well-qualified for the purpose' of teaching Greenwich Hospital boys, a group of whom was first sent to his Academy in $1715 .^{92}$ Their education was to be practical enough for them to be subsequently apprenticed to ships' masters, although Weston also catered to private pupils. ${ }^{93}$ He produced short works for teaching drawing, writing and arithmetic and his Treatise of Arithmetic was published after his death by his brother, John, who took over as master of the Academy. ${ }^{94}$ The Treatise was offered to 'Young Students' and all 'Those who are desirous of being rationally skill'd in the Science of ARITHMETIC' but dedicated to 'The Young Gentlemen of the Academy in Greenwich, For whose USE it was Originally COMPOS'D', suggesting that it existed at an earlier date in manuscript. 
In his preface, Weston outlined a theory of effective education with practical outcomes. He emphasised the 'Universal Usefulness of my Subject' and claimed that he aimed at plain rules so that 'All Mankind' might 'in some measure' understand arithmetic. He wished to present a foundation for study, showing the reason behind each step and, as with Flamsteed and Hodgson, claimed this would help memory better than learning by rote. He emphasised, though, that neither Working by heart' nor being taught 'Practice' alone was sufficient. ${ }^{95}$ Instruments were, again, one route by which abstract mathematics was made concrete. In 1716 Weston requested from the Greenwich Hospital a pair of globes for teaching the boys, alongside a Treatise of the Globes (probably John Senex, 1718), Hodgson's Theory of Navigation and Euclid. ${ }^{96}$ The use of globes, with dividers, would have helped students grapple with textbook problems and diagrams. An advertisement run in February 1727/8, which claimed the Academy's suitability for 'Young Noblemen and Gentlemen', outlined the range of subjects covered: 'Writing, Arithmetick, Merchants Accompts, or the Italian Method of Book-Keeping, Foreign Exchanges, the Mathematicks (in English, Latin or French) Short-hand, Drawing, Fencing, Musick and Dancing', all taught in 'the most rational Way', as well as English, Latin, Greek, Hebrew, French, Italian, High-Dutch and Spanish.

While Hodgson is known as having been a city-based philosophical lecturer, this advertisement shows that Weston could also boast 'frequent Courses of Philosophical Experiments' with 'Explanatory Lectures concerning them' as well as lectures in 'Geometry, Geography and Astronomy three Days a Week'. The school had 13 Masters, five of whom were 'continually in the House', and 'an excellent apparatus of Instruments (Geometrical, geographical, Astronomical and Philosophical)' ${ }^{97}$ The active learning of at least some of his pupils extended to the putting on of theatricals. Tamerlaine was 
performed in 1722, including 'before the Lords of the Admiralty', and Terence's Andria was performed in Latin with 'Roman habits', while their audience for Addison's Cato included 'a great number of the Gentry'. ${ }^{98}$ Weston's Italian was sufficient to allow him to translate Galileo. He demonstrated his historic and literary knowledge, but chose to dedicate the book to Colonel John Armstrong, surveyor-general of the Ordnance, in laudatory terms, noting his 'Experimental, as well as Contemplative Knowledge'. 99

In the 1720s, when both men were active as authors and teachers, Weston and Hodgson commissioned mezzotint portraits. Weston's, dated 1723, was by John Faber the younger after Michael Dahl, while Hodgson's, undated but of around the same time, was by George White after Thomas Gibson (Figures 3 and 4). Both portraits include carefully selected and laid out tools of the mathematical teacher's trade, with perspective sacrificed to legibility. ${ }^{100}$ They act as advertisements for their schools, books and teaching. Weston's portrait may have been intended as the frontispiece to a planned, or lost, mathematical text from around 1723 but was used for his 1726 volume, which had sections on writing, drawing and arithmetic. The image includes a sectioned cone, a diagram of lunar phases and a booklet containing the text of an astronomical lecture. There is also a pen, inkwell and a cased set of drawing instruments, suiting the contexts of calligraphy and of drawing, whether diagrams, figures or landscapes. ${ }^{101}$ Together, the objects suggest the links between these disciplines and the acquisition of hands-on practice. Weston gestures to the cone, inviting the viewer/reader to pick it up, while the rule, sector and dividers might be used to draw or to interrogate texts, diagrams and instruments. ${ }^{102} \mathrm{He}$ appears in a striped, silk banyan, as the scholar at home, perhaps emphasising his status as master of a private academy. 
[Figure 3: Mezzotint of Thomas Weston by John Faber the younger after Michael Dahl, 1723. Wellcome Collection V0006255, CC BY.]

[Figure 4: Mezzotint of James Hodgson by George White, after Thomas Gibson, c. 1720. Wellcome Collection V0002805, CC BY.]

Hodgson, in his more public role, wears a velvet justaucorps with classically inspired drapery over his shoulder. Both men had worked to improve their Latin after having mastered astronomy and mathematics, and Hodgson emphasised his learning with an inscription in Latin that records his position, emphasised as a royal appointment, and his fellowship of the Royal Society. ${ }^{103}$ The portrait does not appear to have been used as a frontispiece but, once again, the attributes of his trade are prominent: a page of diagrams relating to astronomical problems in his System of the Mathematics, the volumes of which are also on the table, an armillary sphere and cross-staff. ${ }^{104}$ The link between mathematics, astronomy and navigation is insisted on, along with the need for both text and instrument, theory and practice. Their intimate relationship is implied by Hodgson's hands, which relate a specific point of the two-dimensional diagram to that on the threedimensional instrument. Once again, the viewer is given an encouraging look, as the pedagogue checks that the connection has been made.

Although it is difficult to trace the influence of these men's works, we know that RMS boys used Hodgson's book to produce navigation cyphers. ${ }^{105}$ Several of the examined copies of these texts bear signatures of owners and contain notes and marginalia. It is, therefore, possible to trace a line from Flamsteed and his assistants to the more persistent attempts to introduce astronomical and mechanical training to mariners and the military 
in the later eighteenth and early nineteenth centuries, not least because Astronomers Royal continued to advise and examine for institutions such as Trinity House and, later, the Woolwich Academy. While Maskelyne and the Board of Longitude found resistance to schemes for training and examining ships' Masters in the $1770 \mathrm{~s}$, Observatory assistants and computers like Charles Green, William Wales and William Bayly successfully taught new techniques, including use of the Nautical Almanac, to officers of the ships on which they were placed as Board of Longitude- or Royal Society-appointed observers. ${ }^{106}$ On their return, Wales and Bayly became mathematical masters, the former at the RMS (1775-98) and the latter at the Naval Academy at Portsmouth (1785-1807). Their practical experience and theoretical knowledge ensured that the tradition linking the Observatory's activities and publications to the education of naval officers was maintained and promoted into the nineteenth century.

\section{Conclusion}

This article has traced some of the ways in which the Royal Observatory in Greenwich transformed, over time, from what might have been a unique habitation for a king's astronomer into a long lasting and, ultimately, widely known institution. While its location close to London was inevitable given the various interests that led to its foundation, it was also its relationships with key networks and institutions that gave it form and on-going existence. A number of these institutions had formal relationships with the Observatory, whether through provision of funds, oversight or legislated business. In other cases the relationships were informal and contingent but nevertheless shaped the Observatory and its outputs, as these found support, markets or interested users and collaborators. While the small establishment and ruptures caused by changes of Astronomer Royal may have acted against a sense of continuity of knowledge and 
purpose, these extended networks - including assistants, pupils, instrument makers and collaborators - acted to ensure some retention and sharing of knowledge and practice.

A particular focus here has been the importance of mathematical teaching, both within the Observatory and as an extension of this regime (or aspects of it) into the context of London's practical mathematical community and schools. Hodgson and Weston were conscious of their connection and debt to Flamsteed and the Royal Observatory and were shaped by it in developing their own priorities in pedagogy. Their books, advertisements, equipment and portraits suggest that they sought to represent their approach as rationally planned, theoretically informed and practically applied. This, it was hoped, would produce the kind of mariner who could put the Observatory's output to use and contribute to the improvement of navigation. While it took more than a century for even elite voyages to fulfil this hope, the ground was surely prepared by the not-insignificant number of pupils taught by Flamsteed, Hodgson, Weston and their successors. This overview has, necessarily, treated other equally significant parts of this extended network only in passing, or not at all. Further research should be done, on the relationships between the Observatory staff and other London-based mathematical practitioners, instrument makers, printers, publishers, artists and individuals based within government and military departments such as the Ordnance, Navy and Excise. The aim of this article has been to highlight the range and depth of such connections and the potential for their further exploration.

In the nineteenth century, the links between the Observatory, the Thames and London, and the nation's imperial and trade interests, seemed obvious. The Greenwich location, neighbouring the Greenwich Hospital School and, later, Royal Naval College, as well as 
the city and its docks and shipping, could not have been better chosen. From 1833 a time ball signalled to mariners, directly delivering astronomically determined time to the trained users of chronometers and sextants. In 1834 the Observatory could be presented as an essential element of national prosperity:

In a country like ours, the commercial relations of which are so extensive, and whose ships, conveying the lives and property of our countrymen to distant climes, are daily trusting for safety and guidance across the pathless waters, to the researches of the astronomer, the maintenance of such an establishment is of the highest importance. ${ }^{107}$

While elements of this vision existed in the founding warrants, the Observatory might have been placed elsewhere - far from London or to its west or, institutionally, within the court or Royal Society alone - and have been understood and have developed quite differently.

\section{Rebekah Higgitt}

School of History, Rutherford College, University of Kent, Canterbury, CT2 7NX, UK. r.higgitt@kent.ac.uk

Acknowledgements: I would like to thank Charlotte Sleigh, Jim Bennett, Noah Moxham and Jasmine Kilburn-Toppin for their advice and suggestions. These, together with the comments of the referees, have been helpful in revising and improving this article.

${ }^{1}$ The standard history remains Eric G. Forbes, A.J. Meadows and Derek Howse, Greenwich Observatory: The Story of Britain's Oldest Scientific Institution, the Royal Observatory at Greenwich and Herstmonceux, 1675-1975, 3 vols, London: Taylor \& Francis, 1975, but see also Graham Dolan, The Royal Observatory Greenwich, 201418, http://www.royalobservatorygreenwich.org/articles.php, accessed 10 August 2018. ${ }^{2}$ Christopher Wren, the king's surveyor of works, 3 December 1681, quoted in Frances Willmoth, 'Introduction: The King's "astronomical observator"' in Frances Willmoth, 
ed., Flamsteed's Stars: New Perspectives on the Life and Work of the First Astronomer Royal, 1646-1719, Woodbridge: Boydell Press, 1997, pp. 1-16, p. 4 (subsequently Flamsteed's Stars).

316 March 1668/9, The Diary of Samuel Pepys

https://www.pepysdiary.com/diary/1669/03/16/. Another version is Hendrick Danckerts, 'View of Greenwich and the Queen's House from the south-east', c. 1670, National Maritime Museum, BHC1818 http://collections.rmg.co.uk/collections/objects/13298.html, accessed 10 August 2018.

${ }^{4}$ See Flamsteed's Stars, especially Jim Bennett, 'Flamsteed's career in astronomy: nobility, morality and public utility', pp. 17-30 and Rob Iliffe, 'Mathematical characters: Flamsteed and Christ's Hospital Mathematical School', pp. 115-144.

${ }^{5}$ Mordechai Feingold, 'Astronomy and strife: John Flamsteed and the Royal Society', in Flamsteed's Stars, pp. 31-48, p. 37-38.

${ }^{6}$ Copies of the warrants from The National Archives have been transcribed at Dolan, op. cit. (1), http://www.royalobservatorygreenwich.org/articles.php?article=977 and http://www.royalobservatorygreenwich.org/articles.php?article=976, accessed 8 August 2018.

${ }^{7}$ Flamsteed enquired whether one was needed on Queen Anne's accession: Flamsteed to James Craggs, chief clerk to the master of the Ordnance, 23 December 1703, Letter 923, Eric G. Forbes, Lesley Murdin and Frances Willmoth, eds, The Correspondence of John Flamsteed the First Astronomer Royal, 3 vols, Bristol: Institute of Physics Publishing, 1995-2002, vol 3, p. 49 (subsequently Correspondence). The Board of Visitors' warrants were renewed on the accession of a new monarch from at least 1765 .

${ }^{8}$ On the various roles that Flamsteed could inhabit, see Bennett, op. cit. (4) and Frances Willmoth, 'Models for the practice of astronomy: Flamsteed, Horrocks and Tycho' in Flamsteed's Stars, pp. 49-75.

${ }^{9}$ Frances Willmoth, 'Mathematical sciences and military technology: the Ordnance Office in the reign of Charles II', in J.V. Field and Frank A.J.L. James, eds, Renaissance and Revolution: Humanists, Scholars, Craftsmen and Natural Philosopher in Early Modern Europe, Cambridge: Cambridge University Press, 1993, pp. 117-131, p. 117.

${ }^{10}$ Derek Howse, Greenwich Time and the Longitude, London: Philip Wilson, 1997, pp. 35-45. On Moore, see Frances Willmoth, Sir Jonas Moore: Practical Mathematics and Restoration Science, Woodbridge: Boydell Press, 1993.

${ }^{11}$ Robert Hooke's Diary, p. 151, quoted in Willmoth, op. cit. (9), p. 180.

${ }^{12}$ On Moore's patronage, see Philip Beeley's article in this special issue.

${ }^{13}$ See Flamsteed's Stars and Adrian Johns, The Nature of the Book: Print and Knowledge in the Making, Chicago and London: University of Chicago Press, 1998, pp. 543-611.

${ }^{14}$ The living was worth $£ 150$ p.a., although part of this paid for a curate. See Ian G. Stewart, “"Professor" John Flamsteed', in Flamsteed's Stars, pp. 145-166, p. 153.

${ }^{15}$ On the ups and downs of Flamsteed's relationship with the Society, see Feingold, op. cit. (5). 
${ }^{16}$ A copy of this warrant is in Newton's papers at Cambridge University Library, MS Add.4006: https://cudl.lib.cam.ac.uk/view/MS-ADD-04006/59, accessed 8 August 2018. See P.S. Laurie, 'The Board of Visitors of the Royal Observatory - I: 1710-1830', Quarterly Journal of the Royal Astronomical Society (1966), 7, pp. 169-185.

${ }^{17}$ Laurie, op. cit. (16), pp. 173-4.

18 Thomas Chicheley, master general of the Ordnance, 28 January 1675/6, Correspondence, vol. 1, p. 909.

${ }^{19}$ Flamsteed, 'The State of the Observatory', 1700, published in Francis Baily, An Account of the Revd John Flamsteed, the First Astronomer Royal, London: printed by William Clowes and Sons by order of the Lords Commissioners of the Admiralty, 1835, p. 190.

${ }^{20}$ Copy of the royal appointment of Edmond Halley, 9 February 1720/21, Royal Greenwich Observatory Archives, Cambridge University Library, RGO 4/302/5 (subsequently RGO).

${ }^{21}$ Richard Dunn and Rebekah Higgitt, Finding Longitude: How Ships, Clocks and Stars Helped Solve the Longitude Problem, Glasgow: Collins, 2014; Derek Howse, Nevil Maskelyne: The Seaman's Astronomer, Cambridge: Cambridge University Press, 1989; Rebekah Higgitt, ed., Maskelyne: Astronomer Royal, London: Hale Books, 2014.

${ }^{22}$ Copies of the appointments of the Astronomers Royal, RGO 4/203/1-8; 'Pay of the Astronomers Royal \& Directors', in Dolan, op. cit. (1), http://www.royalobservatorygreenwich.org/articles.php?article=940, accessed 8 August 2018.

23 'Regulations for the execution of the office of Astronomer Royal', RGO 4/301; Howse, op. cit. (21), pp. 44, 55-56, 60.

${ }^{24}$ Howse, op. cit. (21), pp. 106-108, 121-122, 180-82.

${ }^{25}$ See Rebekah Higgitt, 'Managing, communicating and judging longitude after Harrison, 1774-c.1800', in Alexi Baker et al., The Board of Longitude, 1714-1828 (Palgrave, forthcoming).

${ }^{26}$ See the collection in RGO 4/301-108.

${ }^{27}$ John Gascoigne, 'The Royal Society and the emergence of science as an instrument of state policy', BJHS (1999) 32, pp. 171-184.

${ }^{28}$ Crosthwait to Sharp, 1 June 1721 and 8 August 1728, Baily, op. cit. (19), pp. 314, 362.

${ }^{29}$ Alan Cook, 'Edmond Halley and John Flamsteed at the Royal Observatory', in Flamsteed's Stars, pp. 167-187, quote at p. 187; idem, Edmond Halley: Charting the Heavens and the Seas, Oxford: Clarendon Press, 1998, pp. 377-395

${ }^{30}$ Dolan, op. cit. (1) http://www.royalobservatorygreenwich.org/articles.php?article=999, accessed 21 August 2019.

${ }^{31}$ Crosthwait to Sharp, 10 February 1723/4, Baily, op. cit. (19), p. 356; Anita McConnell, 'Pound, James (1669-1724)', Oxford Dictionary of National Biography (2004), http://www.oxforddnb.com/view/article/22637, accessed 21 August 2018.

32 James Bradley, Miscellaneous Works and Correspondence, ed. by S.P. Rigaud, Oxford: Oxford University Press, 1832, p. lii. 
${ }^{33}$ Dunn and Higgitt, op. cit. (21), Chapters 3-4; Rebekah Higgitt, 'Equipping expeditionary astronomers: Nevil Maskelyne and the development of "precision exploration"” in Fraser MacDonald and C.W.J. Withers, eds, Geography, Technology and Instruments of Exploration, Farnham: Ashgate, 2015, pp. 15-36, pp. 19-23. ${ }^{34}$ Higgitt, op. cit. (33) pp. 24-32.

${ }^{35}$ Derek Howse, Greenwich Observatory, Vol. 3: The Buildings and Instruments, London: Taylor \& Francis, 1975, pp. 75-76, 17, 110, 19. See also Willmoth, op. cit. (10), pp. 186-190.

${ }^{36}$ J.A. Bennett, 'The English quadrant in Europe: instruments and the growth of consensus in practical astronomy', Journal for the History of Astronomy (1992), 23, pp. 1-14.

${ }^{37}$ The Observatory appeared on a trade card used by Bleuler, 1791-1822, and John Field, 1791-93 (Science Museum Inv: 1934-122/7 and 1951-685/32). Both had been apprentices of Edward Nairne, a frequent supplier of instruments to such expeditions. ${ }^{38}$ Unless otherwise indicated, the following information is from 'Assistant grades', in Dolan, op. cit. (1) http://www.royalobservatorygreenwich.org/articles.php?article=999, accessed 9 August 2018, and linked biographies.

${ }^{39}$ Flamsteed to Sharp, 24 March 1708/9, Baily, op. cit. (19), p. 270.

${ }^{40}$ Frances Willmoth, 'Sharp, Abraham (bap. 1653, d. 1742)', in Oxford Dictionary of National Biography, Oxford: Oxford University Press, 2011, http://www.oxforddnb.com/view/article/25206, accessed 9 August 2018; idem, "“The ingenious and unwearied Mr Abraham Sharp": a transitional figure in the making of precision instruments', in Liba Taub and Frances Willmoth (eds.), The Whipple Museum of the History of Science: Instruments and Interpretations, to Celebrate the Sixtieth Anniversary of R.S. Whipple's Gift to the University of Cambridge, Cambridge: Cambridge University Press, 2006, pp. 427-466; 'A list of my pupils Names \& Employments...', RGO 1/15, f. 165 v-166v.

${ }^{41}$ On Hodgson see Larry Stewart, 'Other centres of calculation, or, where the Royal Society didn't count: commerce, coffee-houses and natural philosophy in early modern London', BJHS (1999) 32, pp. 133-153 and idem, The Rise of Public Science: Rhetoric, Technology and Natural Philosophy in Newtonian Britain, 1660-1750, Cambridge: Cambridge University Press, 1992, pp. 111-116.

${ }^{42}$ Mary Croarken, 'Astronomical labourers: Maskelyne's assistants at the Royal Observatory, Greenwich, 1765-1811, Notes and Records of the Royal Society of London (2003) 57, pp. 285-298; Higgitt, op. cit. (33), pp. 15-36.

${ }^{43}$ Iliffe, op. cit. (4); Stewart, op. cit. (14).

${ }^{44}$ RGO 1/15, f. 165v-166v.

${ }^{45}$ Ibid and on Bridges, Historical Register (April 1737) 22, p. 256.

${ }^{46}$ Correspondence, vol. 2, p. 852; draft petition to Queen Anne, 29 Deember 1710, ibid, vol. 3, p. 576.

${ }^{47}$ On Flamsteed and the RMS, see Iliffe, op. cit. (4).

${ }^{48}$ James Thornhill, An Explanation of the Painting in the Royal Hospital at Greenwich, [London, 1726], p. 10 (facsimile, Old Royal Naval College, 2017). 
${ }^{49}$ Kim Sloan, 'The teaching of non-professional artists in eighteenth-century England', unpublished $\mathrm{PhD}$ thesis, University of London, 1986, p. 75; idem, 'Thomas Weston and the Academy at Greenwich', Transactions of the Greenwich and Lewisham Antiquarian Society (1984) 9, pp. 313-333; J.W. Kirby, 'Early Greenwich schools and schoolmasters', Transactions of the Greenwich and Lewisham Antiquarian Society (1929) 3, pp. 218-241. Weston's brother John later took over the Academy and as examiner.

${ }^{50}$ Flamsteed to Lord Aston, 20 February 1702/3, Letter 891, Correspondence, vol 2, p. 1002.

${ }^{51}$ Henry Stanyan to Flamsteed, 30 August/10 September 1706, Letter 1118, Correspondence, vol. 3, p. 346.

${ }^{52}$ Rob Iliffe and Frances Willmoth, 'Astronomy and the domestic sphere: Margaret Flamsteed and Caroline Herschel as assistant-astronomers', in Lynette Hunter and Sarah Hutton (eds.), Women, Science and Medicine 1500-1700, Stroud: Sutton, 1997, pp. 235265.

${ }^{53}$ Stanyan to Flamsteed, 1/12 May 1706, Letter 1088, Correspondence, vol. 3, p. 309.

${ }^{54}$ Flamsteed to Sharp, 12 July 1707 and 23 July 1708, Letters 1180 and 1209, Correspondence, vol. 3, pp. 433, 478.

${ }^{55}$ Iliffe and Willmoth, op. cit. (52), p. 253

${ }^{56}$ Johns, op. cit. (13), pp. 612-617; Iliffe and Willmoth, op. cit. (52), pp. 254-255; Cook, op. cit. (29), pp.178-183; Flamsteed's account and correspondence between Crosthwait and Sharp are in Baily, op. cit. (19).

${ }^{57}$ Frontispiece engraved by George Vertue, after Giovanni Battista Catenaro, in John Flamsteed, Historiae coelestis libri duo..., 2 vols, London: J. Mathews, 1712, vol. 1. ${ }^{58}$ Frontispiece engraved by George Vertue, after Thomas Gibson, in John Flamsteed Historia Coelestis Britannica, 3 vols, London: H. Meere, 1725, vol. 1; Allan Chapman, ed., The Preface to John Flamsteed's Historia Coelestis Britannica, or, British Catalogue of the Heavens (1725), trans Alison Dione Johnson, London: National Maritime Museum, 1982.

${ }^{59}$ Crosthwait told Sharp in a letter of 6 May 1720, 'we can depend upon very little from Mr. Hodgson', Baily, op. cit. (19), p. 335

${ }^{60}$ Warrant, 15 February 1724, British Library, Evelyn Papers, Add MS 78683, f. 172. I am grateful to Elizabeth Yale for this reference. Margaret Flamsteed's not rewarding Crosthwaite has been attributed to the $£ 1000$ stock she inherited losing value, but this would have been regained after 1720: see Helen J, Paul, 'The "South Sea Bubble", 1720', European History Online (2015) http://www.ieg-ego.eu/paulh-2015-en, accessed 9 August 2018.

${ }^{61}$ Margaret Flamsteed's will, made 23 December 1728, proved 30 July 1730, Correspondence, vol. 3, pp. 940-942. On Tycho as a model, and the portraits, see Willmoth, op. cit. (8), pp. 62-75. The Oxford pair were lent to the Museum for the History of Science in 2001 (Flamsteed after Thomas Gibson, 1712, Inv: 49865; Tycho Brahe, anonymous, seventeenth century, Inv. 18236); the Royal Society pair were 
presented in 1732 (Flamsteed by Thomas Murray, c. 1680; Tycho Brahe, unknown, c. $1620 \mathrm{~s})$.

${ }^{62}$ Orders and instructions to Captain John Pelly, Thomas Liell and John Hodgson, Supercargoes of the Princes of Wales, bound for Banjarmassin and Canton, 12 October 1737, East India Company Letter Books, British Library, E/3/107, ff. 134v-39. His death on 14 November 1751, and a legacy of £200pa for his father, is recorded in The London Magazine (1751) 20, p. 525.

${ }^{63}$ Flamsteed to Abraham Sharp, 18 June 1719, Letter 1505, Correspondence, vol. 3, p. 914.

${ }^{64}$ Frances Willmoth, 'Hodgson, James (bap. 1678?, d. 1755)', Oxford Dictionary of National Biography, http://oxforddnb.com/view/article/13437, accessed 21 August 2018; Derek Howse, 'The Tompion clocks at Greenwich and the dead-beat escapement, with an Appendix by Beresford Hutchinson', Antiquarian Horology (1970) 12, pp. 18-34 and (1971) 3, pp. 114-133 ; Thomas Tompion, year-going clock, 1676, British Museum 1928,0607.1; Venetian object glass, R.S. 25, Science Museum Inv: 1932-460; Meeting of 23 November 1732, Journal Book, Royal Society, JBO/15, p. 185. Hodgson also gifted a number of books, for which he was excused his debts: Meeting 20 August 1730, Council Minutes, Royal Society, CMO/3/28.

${ }^{65}$ Museum of the History of Science, 'The Noble Dane: Images of Tycho Brahe', https://www.mhs.ox.ac.uk/tycho/catfm.htm?tycho, accessed 9 August 2018. The Bodleian in fact received a copy and the original remained with John Hodgson's heirs until given to the Royal Society by John Belchier: meeting of 7 May 1772, JBO/27, pp. 622-623. Belchier represented Elizabeth Tew, wife of John Hodgson's executor John Tew, when she sold Flamsteed's papers in 1771.

${ }^{66}$ Flamsteed to Abraham Sharp, 18 December 1703, Letter 92, Correspondence, vol 3, p. 48.

${ }^{67}$ Halley to [John Arbuthnot], 6 May 1711, Letter 1295, Correspondence, vol. 3, p. 602.

${ }^{68}$ Correspondence, vol. 3, p. 673 (note); Laurie, op. cit. (16), p. 172.

${ }^{69}$ Flamsteed to John Wallis, 24 June 1701, Baily, op. cit. (19), p. 197.

${ }^{70}$ Iliffe, op, cit. (4), p. 144.

${ }^{71}$ Flamsteed to Sharp, 21 October 1705, Letter 949, Correspondence, vol. 3, p. 91;

Nerida F. Ellerton and M.A. Clements, Samuel Pepys, Isaac Newton, James Hodgson, and the Beginnings of Secondary School Mathematics: A History of the Royal Mathematical School within Christ's Hospital, London 1673-1868, Cham, Switzerland: Springer International Publishing, 2017, pp. 122-142.

72 James Hodgson, The Theory of Navigation Demonstrated: and Its Rudiments Clearly and Plainly Proved, from the First and most Simple Principles of the Mathematicks..., London: printed for I. Dawkes, for Richard Mount and Company, 1706, p. 5. Flamsteed made similar comments to Pepys, 21 April 1697, regarding RMS teaching: Iliffe, op. cit. (4), pp. 140-143.

${ }^{73}$ Jonas Moore, A New Systeme of the Mathematicks, London: Printed by A. Godbid and J. Playford for Robert Scot, 1681, Vol. 2, Book 2, p. 3.

${ }^{74}$ Hodgson, op. cit. (72), pp. 8, 307. 
${ }^{75}$ Dedication to George I, in James Hodgson, A System of the Mathematics, 2 vols, London, printed for Thomas Page, William and Fisher Mount, 1723.

${ }^{76}$ Hodgson, op. cit. (75), vol. 1, pp. v, 208.

${ }^{77}$ Hodgson, op. cit. (75), vol. 1, p. 373 and ff.

${ }^{78}$ Hodgson, op. cit. (75), vol. 1, p. 377. Flamsteed said similar to Pepys, 21 April 1697: see Iliffe, op. cit. (4), pp. 140-143. See also James Hodgson, The Theory of Jupiter's Satellites, with the Construction and use of the Tables for Computing their Eclipses, London: printed for the author and sold by W. and J. Mount and T. Page, 1749. This said the work was done 'At the request of my worthy kind Friend and Relation, the late Revered Mr John Flamsteed, His Majesty's Astronomer-Royal' and emphasised their interest in training 'a Set of skillful able Men' able to navigate and make useful observations.

${ }^{79}$ Hodgson, op. cit. (75), vol. 1, p. 379.

${ }^{80}$ Hodgson, op. cit. (75), vol. 1, p. 380.

${ }^{81}$ Hodgson, op. cit. (75), vol. 1, pp. 382-383.

${ }^{82}$ Hodgson, op. cit. (75), vol. 1, p. 385.

${ }^{83}$ John Witty, A Treatise of the Sphere; Shewing How it is deriv'd from the Theory which justly Asserts the Motion of the Earth, London, printed by J. Leake for John Wyat, 1714, Chapter IV, Section II. Hodgson also revised and published the second edition of 1734.

${ }^{84}$ Iliffe and Willmoth, op. cit. (52), pp. 251-252; 'John Witty' in Dolan op. cit. (1), http://www.royalobservatorygreenwich.org/articles.php?article=1152, accessed 10 August 2018.

${ }^{85}$ Hodgson, op. cit. (75), vol 1, pp. 81-82. See Correspondence, vol. 3, pp. 195, 910, 914, 925. Hodgson told Flamsteed he was including the method in a second edition of his Theory of Navigation (c. 1720), of which there are no surviving copies.

${ }^{86}$ Hodgson, op. cit. (75), vol 2, pp. x, 512, 513, 515.

${ }^{87}$ Hodgson, op. cit. (75), vol. 2, p. 430.

${ }^{88}$ Iliffe, op. cit. (4); Margaret Schotte, 'Hands-on theory at the Royal Mathematical School - Deptford, 1683', paper at Das Meer conference, Wolfenbüttel, 5-7 October 2017; idem, Sailing School: Navigating Science and Skill (forthcoming, Johns Hopkins University Press, 2019).

${ }^{89}$ Clifford Jones, The Sea and the Sky: The History of the Royal Mathematical School of Christ's Hospital, Horsham: Clifford Jones, 2015, pp. 97-98; Schotte, op, cit. (81).

${ }^{90}$ Ellerton and Clements, op. cit. (71), p. 125.

${ }^{91}$ Baily, op. cit. (18), pp. 64, 65.

${ }^{92}$ Royal Hospital minutes, 4 November 1715, quoted in in Sloane (1984), op. cit. (49), p. 318.

${ }^{93}$ Kirby, op. cit. (49), p. 232.

94 Thomas Weston, A Copy-Book Written for the Use of the Young-Gentlemen at the Academy in Greenwich [London], 1726; idem, Drawing-Book compos'd for the use of the young gentlemen at the Academy in Greenwich [London, 1726]; idem, Veteris arithmeticae elementa: sive De symbolicis et practicis partibus arithmeticae, ab antiquis hebraesis, graecis et romanis usurpatae ... tractatus: in usum studiosae juventutis in 
Academiâ Grenovici... [London, 1726]; idem, Thomas Weston, A Treatise of Arithmetic, in Whole Numbers and Fractions..., London; published by John Weston, printed for J. Hooke, 1729.

${ }^{95}$ Weston (1729), op. cit (94), preface.

${ }^{96}$ Sloan (1984), op. cit. (49), p. 318.

${ }^{97}$ Quoted in Sloan (1984), op. cit. (49), pp. 321-322.

${ }^{98}$ Kirby, op. cit. (49), p. 233; London Journal (14 Dec 1723), p. 3. The audience for Cato on 12 December 1723 included the Countess of Albermarle, granddaughter of two individuals linked to the foundation of the ROG, Charles II and Louise de Kérouaille. ${ }^{99}$ Dedication by John Weston in Galileo Galilei, Mathematical Discourses Concerning the Two New Sciences Relating to Mechanical and Local Motion, trans. Thomas Weston, London: published by John Weston and printed for J. Hooke, 1730.

${ }^{100}$ Comparative examples of portraits of practical mathematicians, particularly instrument makers, are discussed in Celina Fox, The Arts of Industry in the Age of Enlightenment, New Haven and London: Yale University Press, 2009, pp. 313-335 and Ludmilla Jordanova, Defining Features: Scientific and Medical Portraits 1660-2000, London: Reaktion Books, 2000, pp. 54-61.

${ }^{101}$ On Weston's Copy-Book, which focused on figure drawing and landscapes, see Sloan, op, cit. (49) and Chia-Chuan Hsieh, 'The emergence and impact of the 'complete drawing book' in mid-eighteenth-century England', Journal for Eighteenth Century Studies (2013), 36, pp. 395-414, pp. 399-400.

${ }^{102}$ Similar sets made by Thomas Heath are Science Museum Inv 1954-327 and 1918121.

${ }^{103}$ Flamsteed told Sharp that Hodgson was 'perfecting his knowledge of the Latin tongue. the Fluxions and series', 12-13 December 1705, Letter 1059, Correspondence, vol. 3 , p. 268.

${ }^{104}$ The diagrams are from Hodgson, op, cit. (75), vol. 2, pp. 260, 262, on stereographical solutions to a problem about finding the amplitude of the Sun on the plane of the ecliptic, horizon and equator. This problem was 'the principal Thing wanting at present to render the several Method hitherto proposed by Astronomers, for finding the Longitude at Sea practicable' (p. 287).

${ }^{105}$ Ellerton and Clements, op. cit. (71), pp. 105-110.

${ }^{106}$ Higgitt, op. cit. (33), pp. 25-26, 32-35. Learning could go both ways, see Jim Bennett, 'Mathematicians on board: introducing lunar distances to life at sea', BJHS (2019) 52, pp. 65-83.

107 'The Royal Observatory, Greenwich’, Weekly Visitor (1835) 129, p. 69. 